Topik: Manajemen Negara dan Nasionalisme

\title{
Peran Hukum Internasional dan Perbatasan Wilayah Negara
}

\author{
Pudak Nayati
}

\begin{abstract}
Recently Indonesia is facing the issues of the border with Malaysia. After facing the Sipadan and Ligitan conflict, Indonesia and Malaysia have been disputing to claim the Ambalat area. A region is an important factor of a country. The alteration of the border of a region does not change the status of a country. Also, an unclear border of a region does not altemate the existence of a country. This paper describes some theories relating to the role of the Intemational Law in a country's border. Some discusses the profile of the border of indonesia relating to its neighboring countries, such as Thailand and Australia. This paper also analysis the role of the Intemational Law in the issue of country's border, particularly indonesia, focusing the on the intermal and extemal functions of the intemational Law. The external function could be used as a base of indonesian diplomacy at the international level. The internal function would be utilized as a tool to harmonize the National Law of Indonesia, however, this is not conducted yet.
\end{abstract}

Kata kunci: hukum Internasional, konflik perbatasan, dan peran Indonesia

$\mathrm{B}^{\mathrm{e}}$ eberapa tahun belakangan ini, negara Indonesia dihadapkan oleh berbagai permasalahan perbatasan wilayah dengan negara tetangga. Setelah menghadapi permasalahan Pulau Sipadan dan Ligitan dengan negara jiran Malaysia, Indonesia saat ini juga harus menghadapi permasa- lahan Kawasan Ambalat dengan negara Malaysia. Belum lagi terjadinya pergeseran patok-patok perbatasan wilayah Indonesia dan Malaysia di daerah Kalimantan. Di samping itu, potensi permasalahan-permasalahan perbatasan wilayah lain Sangat mungkin akan menghadang Indonesia di kemudian hari. Dari permasalahan-permasalahan perbatasan wilayah Indonesia dengan negara tetangga ini, kemudian timbul pertanyaan yang mendasar: 'Dimana gerangan Hukum Internasional selama ini? Apakah Hukum Internasional mempunyai fungsi dalam permasalahan-permasalahan perbatasan ini? Dalam bentuk apakah fungsi tersebut diterapkan?'

Dari permasalahan-permasalahan perbatasan wilayah yang sedang dihadapi Indonesia saat ini, sebenarnya ada dua hal yang berbeda yang harus dicermati. Yang pertama adalah permasalahan perbatasan wilayah negara yang timbul karena memang belum ada kesepakatan perbatasan antar negara. Seperti misalnya, permasalahan Pulau Sipadan - Ligitan, dan kasus Kawasan Ambalat antara Indonesia dan Malaysia. Dalam dua kasus ini, permasalahan perbatasan wilayah timbul sebagai akibat belum disepakatinya perbatasan landas 
kontinen antara kedua negara. Kedua, permasalahan perbatasan wilayah yang timbul setelah kesepakatan perbatasan wilayah antar negara terformulasikan. Hal ini dapat dicontohkan dengan kasus bergesemya patok perbatasan antarnegara Indonesia dan Malaysia di Kalimantan, atau kasus reklamasi pantai Singapura. Masingmasing masalah mempunyai metode pendekatan yang berbeda.

Tulisan ini berusaha memaparkan bagaimana peran Hukum Internasional dalam permasalahan perbatasan wilayah negara, dalam hal ini, Indonesia. Akan tetapi, sebelumnya, akan diuraikan teori-teori yang berkaitan dengan Peran Hukum Internasional bagi suatu negara, dan tentang perbatasan wilayah negara.

\section{Peran Hukum Internasional Bagi Suatu Negara'}

Hukum Internasional adalah sekumpulan aturan yang mengatur hubungan antar negara dan antar subyek Hukum Internasional lainnya. Awalnya, subyek Hukum Internasional yang pertama dan utama (par excellence) hanyalah negara. Akan tetapi, dengan perkembangan Hukum Internasional dewasa ini, subyek Hukum Internasional tidak hanya negara saja.

Pada saat menjawab pertanyaan mengenaj sumber-sumber Hukum Intemasional, maka titik langkah awal yang digunakan adalah Pasal 38 Statuta Mahkamah Internasional PBB. Meskipun Statuta ini, dan Pasal ini khususnya, hanya mengatur mengenai kerangka bekerjanya hakim-hakim Miahkamah Internasioal PBB, akan tetapi dari Pasal ini terlihat bukti praktik negara-negara dalam mencari dan menggunakan isi Pasal 38 tersebut sebagai salah satu sumber Hukum Internasional. Akan tetapi, sumber Hukum Internasional tidaklah terbatas hanya yang tercantum dalam Pasal 38 Statuta Mahkamah Internasional. Masih banyak sumbersumber Hukum Internasional lain yang esquís diluir sumber-sumber yang tercantum dalam Pasal 38 tersebut.

Pasal 38 Statuta Mahkamah Internasional PBB menyatakan bahwa dalam menyelesaikan perkara, maka hakim-hakim Mahkamah Internasional PBB harus menerapkan perjanjian-perjanjian internasional, hukum kebiasaan internasional, dan prinsip-prinsip umum Hukum Internasional. Selain itu, sebagai alat tambahan, dapat menggunakan putusan-putusan pengadilan -intemasional maupun nasional - serta tulisan/pendapat para ahli Hukum Internasional.

Dari sebuah perjanjian internasional bilateral antar dua negara, dapat menjadi hukum kebiasaan internasional apabila perjanjian bilateral itu kemudian substansinya ditiru oleh negara-negara lain, dipraktikkan secara konsisten dan lama kelamaan dianggap sebagai hukum (opinio juris necessitatis).

Dari uraian di atas maka dapat dikatakan bahwa Hukum Intemasional mempunyai hubungan yang erat dengan Hukum Nasional. Hukum Internasional dapat mempengaruhi Hukum Nasional. Demikian .juga sebaliknya, Hukum Nasional mungkin dapat menjadi Hukum intemasional apabila Hukum Nasional suatu negara ditiru oleh negara-negara lain, dipraktikkan secara konsisten, dan lama kelamaan dianggap sebagai hukum.

1 Lihat Martin Dixon, Textbook on International International Law, 4th Ed. Blackstone, London, 2000; John O'Brien, International Law Cavendish, London, 2001; dan buku-buku Hukum Internasional lainnya. 
Hukum Internasional bagi suatu negara mempunyai fungsi keluar dan ke dalam. Untuk fungsi keluar, Hukum Internasional menjadi dasar dan guidelines dalam melakukan hubungan dengan negara-negara lain di tataran internasional. Sedangkan untuk fungsi kedalamnya, Hukum Internasional memberikan inspirasi pembentukan Hukum Nasional.

\section{Perbatasan Wilayah Negara}

Berdasarkan Konvensi Montevideo 1933, salah satu unsur dari negara adalah wilayah. Di wilayah ini, negara memiliki kedaulatan. Dengan kedaulatan ini, suatu negara memiliki kekuasaan untuk menerapkan hukumnya, atau yang sering disebut sebagai yurisdiksi negara, terhadap apapun juga dan siapapun juga - baik warga negaranya sendiri maupun warga negara asing - yang terjadi dan berada di dalam wilayah negara tersebut. ${ }^{2}$

Wilayah merupakan unsur yang sangat penting dari suatu negara. Tidak akan ada suatu negara apabila tidak memiliki wilayah. Perubahan perbatasan wilayah tidaklah merubah status suatu negara, demikian pula dengan ketidakjelasan perbatasan wilayah suatu negara. Seperti misalnya, ketidakjelasan perbatasan wilayah daratan antara Israel dan Palestina, tidaklah merubah status Israel sebagai suatu negara. Akan tetapi, ketidakjelasan perbatasan wilayah ini rentan terhadap konflik antar negara berkaitan dengan batas wilayah antara negara-negara tersebut.

Wilayah negara terdiri dari wilayah daratan, wilayah perairan dan wilayah udara. Tidak semua negara memiliki wilayah perairan. Hal ini berlaku bagi land-locked states (negara-negara yang dikelilingi/ "dikunc" oleh wilayah daratan negara-negara tetangganya), seperti misalnya negara Irak.
Akan tetapi, setiap negara pasti memiliki wilayah daratan dan wilayah udara. ${ }^{3}$

Dalam Hukum Laut Internasional, perairan dibagi-bagi menjadi beberapa zona laut. Semakin jauh zona laut tersebut dari pantai suatu negara, semakin menipis kedaulatan dan yurisdiksi yang dimiliki negara tersebut akan zona laut tersebut. ${ }^{4}$

Pengukuran lebar setiap zona laut ini dimulai dari garis pangkal. Garis pangkal ini juga menjadi awal pengukuran penentuan pembagian zona laut dengan negara tetangga apabila zona laut tersebut berhimpitan dengan zona laut yang dimiliki oleh negara tetangga itu. Garis pangkal ini terdapat tiga macam, yaitu garis pangkal normal/biasa (normal baseline), garis pangkal lurus (straight baseline), dan garis pangkal lurus kepulauan (archipelagic baseline). Garis pangkal normal adalah garis air laut surut yang mengikuti pantai. Sedangkan garis pangkal lurus adalah garis yang ditarik dengan cara menghubungkan titik-titik terluar pada pulau-pulau terluar pada saat air laut surut. Garis pangkal lurus kepulauan hanya dapat diterapkan oleh negara kepulauan seperti yang didefinisikan oleh 1982 United Nations Convention on the Law of the Sea (Konvensi Hukum Laut 1982/ UNCLOS). ${ }^{5}$

Zona laut yang berada di dalam garis pangkal adalah perairan pedalaman. Kedaulatan negara pantai atas perairan pedalaman ini adalah penuh seperti kedaulatan negara yang bersangkutan atas wilayah daratannya. Perairan yang lebamya 12 mil laut diukur dari garis pangkal adalah

\section{2 lbid}

${ }^{3} \mathrm{lbid}$

${ }^{4}$ R.R. Churchil dan A.V. Lowe, The Law of the Sea, 2nd Ed, Manchester, U.K., 1991.

$$
5 \text { lbid }
$$


zona laut teritorial. Kedaulatan yang dimiliki oleh negara pantai atas laut teritorial ini meliputi dasar laut teritorial dan tanah $\mathrm{di}$ bawahnya. ${ }^{6}$

Zona tambahan adalah perairan yang diukur 24 mil laut dari garis pangkal. Meskipun pengukurannya dimulai dari garis pangkal, akan tetapi zona tambahan itu sendiri terletak mulai di luar batas terluar dari laut teritorial. Di zona ini, negara pantai hanya memiliki kedaulatan atas masalah imigrasi, sanitari dan fiskal saja. ${ }^{7}$

Zona laut yang lain adalah Zona Eksklusif Ekonomi (ZEE). Zona ini adalah perairan yang berada di luar batas terluar laut teritorial. Lebar ZEE ini tidak boleh melebihi 200 mil laut diukur dari garis pangkal. Negara pantai hanya memiliki hak berdaulat atas eksplorasi dan eksploitasi, pelestarian dan pengelolaan sumber daya alam hayati dan non hayati yang berada di dalam ZEE. ${ }^{8}$

Selain itu, dikenal adanya landas kontinen. Landas kontinen adalah dasar laut dan tanah dibawahnya dimulai dari batas terluar dari laut teritorial. Lebar landas kontinen ini adalah 200 mil laut sampai $\mathbf{3 5 0}$ mil laut diukur dari garis pangkal. Dengan kata lain, apabila zona-zona laut itu mengatur mengenai kolom airnya, maka landas kontinen mengatur mengenai dasar laut dan tanah dibawahnya mulai dari batas terluar dari laut teritorial. ${ }^{9}$

Sangat dimungkinkan bahwa pengukuran zona-zona laut dan landas kontinen ini tumpang tidih dengan negara tetangga yang berhadapan atau berdampingan. Zonazona yang dimungkinkan tumpang tindih ini adalah laut teritorial, ZEE, dan landas kontinen. Apabila terjadi tumpang tidih seperti ini, maka UNCLOS mengatur untuk menyelesaikannya melalui perjanjian internasional antara negara-negara yang terkait, dengan mendasarkan diri pada teoriteori delimitasi batas laut yang telah diatur dalam UNCLOS. ${ }^{10}$

Untuk wilayah udara, suatu negara memiliki kedaulatan dan yurisdiksi di wilayah udara yang berada di atas wilayah daratan dan wilayah lautnya (apabila negara tersebut memiliki perairan). Kedaulatan dan yurisdiksi suatu negara hanya berlaku di ruang udara di atas wilayah daratannya dan di atas perairan pedalaman dan laut teritorial. Suatu negara sudah tidak mempunyai kedaulatan dan yurisdiksi di atas ruang udara di atas zona-zona laut diluar batas luar laut teritorial. ${ }^{11}$

\section{Profil Batas Wilayah Negara Indonesia}

Sebagai suatu negara kepulauan, Indonesia tidak hanya memiliki perbatasan wilayah daratan dengan negara tetangga, akan tetapi juga memiliki perbatasan wilayah laut dengan negara lain. Indonesia hanya memiliki perbatasan wilayah daratan dengan tiga negara tetangga, yaitu Malaysia, Papua New Guinea (PNG) dan Timor Leste. ${ }^{12}$ Sedangkan untuk perbatasan wilayah laut, Indonesia mempunyai perbatasan dengan sepuluh negara tetangga, yaitu dengan India, Malaysia, Singapura, Thailand, Filipina,

\section{${ }^{6} \mathrm{lbid}$ \\ 7 Ibid \\ \& Ibid \\ 9 Ibid \\ ${ }^{10} \mathrm{lbid}$}

$"$ Lihat Martin Dixon, Textbook on International international Law, 4th Ed. Blackstone, London, 2000; John O'Brien, Intemational Law Cavendish, London, 2001; dan buku-buku Hukum Internasional lainnya.

12 Sobar Sutisna, "Batas-batas Intemasional NKRF", Makalah yang disampaikan dalam Seminar Batas Wilayah Negara, Teknik Geodesi UGM, 3 Mei 2005, hlm. 2. 
Vietnam, Palau, PNG, Australia, dan Timor Leste. ${ }^{13}$

Untuk batas wilayah daratan antara Indonesia dan negara-negara tetangga, sebagian besar sudah terdapat perjanjian perbatasan. Untuk perbatasan wilayah daratan antara Indonesia dan Malaysia di Kalimantan dan pulau Sebatik (disebelah Timur pulau Kalimantan), kesepakatan antar dua negara ini mengacu pada perjanjian perbatasan Treaty 1891 antara Inggris (yang waktu itu menjajah Malaysia) dan Hindia Belanda (menjajah Indonesia pada saat itu), serta Konvensi 1951 dan 1928. Untuk perbatasan wilayah daratan dengan PNG, Indonesia dan PNG menggunakan perjanjian perbatasan antara Hindia Belanda dan Inggris (yang menjajah PNG saat itu), yang kemudian diperbaharui dengan perjanjian batas wilayah daratan antara Indonesia dan Autralia (yang kemudian menjajah PNG saat itu). Kesepakatan terakhir antara Indonesia dan PNG kemudian dituangkan Indonesia di Undang-Undang No. 6 Th. 1973. Sedangkan kesepakatan perbatasan wilayah daratan antara Indonesia dan Timor Leste disepakati pada tanggal 8 April 2005 dan dituangkan ke dalam Provisional Agreement. ${ }^{14}$ Akan tetapi, selain itu masih terdapat beberapa titik batas wilayah daratan antara Indonesia dan tiga negara ini yang belum terdapat kesepakatan. Titik-titik tersebut yaitu sepuluh tempat antara indonesia dan Malaysia di wilayah Kalimantan, tiga tempat di perbatasan antara Indonesia dengan Timor Leste. Selain itu masih ada beberapa tempat yang belum dilakukan survei lapangan diperbatasan di Kalimantan, Irian dan pulau Timor. ${ }^{15}$

Untuk perbatasan wilayah laut, Indonesia memiliki perbatasan laut dengan sepuluh negara tetangga, yang meliputi batas wilayah laut teritorial, batas wilayah perairan Zona Ekonomi Eksklusif (ZEE), dan batas wilayah landas kontinen. Perjanjian perbatasan wilayah laut antara Indonesia dengan negara-negara tetangga tersebut belum tuntas secara keseluruhan. Masih banyak titik batas laut - baik batas laut teritorial, batas ZEE, maupun batas landas kontinen - yang belum selesai.

Batas wilayah laut teritorial yang telah disepakati antara Indonesia dan negara jiran antara lain di selat Malaka (Indonesia-Malaysia, pada tahun 1970, dan kemudian diratifikasi oleh Indonesia dengan UU No. 2 Th. 1971), dan batas wilayah laut teritorial antara Indonesia dan PNG. Sedangkan batas wilayah laut teritorial antara Indonesia dan Singapura di Selat Singapura sudah terdapat kesepakatan diantara kedua negara pada tahun 1973. ${ }^{16}$

Akan tetapi, perjanjian perbatasan wilayah laut teritorial antara Indonesia dan Singapura di Selat Singapura di atas belum meliputi wilayah utara Pulau Karimun dan sebelah utara Pulau Bintan. Hal ini disebabkan karena wilayah tersebut merupakan perbatasan antara tiga negara, yaitu Indonesia, Malaysia dan Singapura. Sehingga untuk titik-titik ini, belum ada perjanjian perbatasan wilayah laut teritorialnya. Untuk perbatasan wilayah laut teritorial antara Indonesia dan Timor Leste, masih memerlukan penentuan garis pangkal di beberapa pulau, yaitu di Pulau Timor, Pantar, Alor, Liran, Wetar, Kisar, dan Leti. ${ }^{17}$

${ }^{13}$ Rusdi Ridwan, “Batas Marjtim antara Republik Indonesia dengan Negara Tetangga", Makalah yang disampaikan dalam Seminar Batas Wilayah Negara, Teknik Geodesi UGM, 3 Mei 2005.

${ }^{14}$ Sobar Sutisna, op.cit., hlm. 3

$15 \mathrm{Ibid}$.

16 Ibid., hlm. 6-7. Lihat juga: Rusdj Ridwan, op.cit.

17 lbid., Lihat juga: Rusdi Ridwan, lbid. 
Untuk batas wilayah ZEE, Indonesia telah memitiki perjanjian perbatasan wilayah ZEE dengan Australia. Perbatasan wilayah ZEE antara Indonesia dan Australia di laut Arafura sampai di laut Timor, disepakati pada tahun 1997. Demikian pula perbatasan wilayah laut ZEE di Samudera Hindia di sekitar Pulau Christmas (Australia) juga telah disepakati pada tahun yang sama, yaitu 1997. ${ }^{18}$ Dengan Vietnam, Indonesia memiliki kesepakatan batas ZEE di Laut Cina Selatan. ${ }^{19}$ Di Laut Sulawesi, Indonesia belum memiliki kesepakatan batas wilayah ZEE dengan Malaysia. Indonesia pun belum mencapai kesepakatan batas wilayah ZEE dengan negara Palau di Samudera Pasifik. ${ }^{20}$ Selain itu, batas wilayah ZEE antara Indonesia dan Timor Leste pun belum dirundingkan. ${ }^{21}$

Sedangkan untuk batas wilayah landas kontinen, Indonesia telah memiliki beberapa perjanjian perbatasan dengan negara-negara tetangga, meskipun belum semua titik perbatasan wilayah landas kontinen telah disepakati antar Indonesia dan negara tetangga. Perjanjian perbatasan wilayah landas kontinen yang telah dimiliki Indonesia adalah antara Indonesia dan India, yaitu di Laut Andaman, Samudera Hindia dan Pulau Nicobar Besar, yang disepakati tahun 1974, dengan Keppres No. 51 Th. 1974. Di Laut Andaman ini pula, Indonesia memiliki kesepakatan perbatasan wilayah landas kontinen dengan Thailand pada tahun 1977 (Keppres No. 1 Th. 1977), dan dengan Thailand dan India pada tahun 1978 (Keppres No.24 Th. 1978). ${ }^{22}$

Selain di Laut Andaman, Indonesia juga telah memiliki perjanjian perbatasan landas kontinen di Selat Malaka dengan Thailand (Keppres No. 1 Th. 1977 dan Keppres No. 21 Th. 1977). Di Selat Malaka Indonesia pun telah memiliki perjanjian perbatasan landas kontinen secara trilateral dengan Thailand dan Malaysia (Keppres No. 20 Th. 1972). Indonesia juga telah memiliki perjanjian perbatasan wilayah landas kontinen di Selat Malaka dengan Malaysia pada tahun 1969 (Keppres No. 89 Th. 1969). ${ }^{23}$

Untuk di Laut Natuna, Indonesia telah mencapai kesepakatan perbatasan wilayah landas kontinen dengan Malaysia. Perjanjian perbatasan landas kontinen Indonesia - Malaysia di Laut Natuna ini meliputi Laut Natuna sebelah Barat dan Timur (Keppres No. 89 Th. 1969). ${ }^{24}$

Dengan Australia, Indonesia telah memiliki perjanjian perbatasan wilayah landas kontinen di Laut Arafura dan Laut Timor (Keppres No. 42 Th. 1971 dan Keppres No. 66 Th. 1972). Sedangkan perjanjian perbatasan wilayah landas kontinen antara Indonesia dan Australia di Samudera Hindia di sebelah Selatan Nusa Tenggara dan di sekitar Pulau Christmas (Australia) telah di sepakati pada tahun $1997 .{ }^{25}$

Di Laut Cina Selatan, Indonesia juga telah memiliki perjanjian perbatasan wilayah landas kontinen dengan Vietnam. ${ }^{26}$

Sedangkan di beberapa tempat, Indonesia belum memiliki kesepakatan batas wilayah landas kontinen dengan beberapa negara tetangga. Di Laut Sulawesi, Indonesia belum memiliki kesepakatan batas wilayah landas kontinen dengan Malaysia. Demikian pula, batas wilayah landas kontinen antara Indonesia dan Palau di

${ }^{18} \mathrm{Ibid}$, him. 7. Lihat pula: Rusdi Ridwan., Jbid.

${ }^{19} \mathrm{Ibid}$., hlm. 8. Lhat juga: Rusdj Ridwan., Ibid.

${ }^{20}$ lbid, Lihat juga: Rusdi Ridwan, lbid.

${ }^{21} \mathrm{Ibid}$, him. 9. Lihat juga: Rusdi Ridwan, Ibid.

22 Ibid. Lihat juga: Rusdi Ridwan, Ibid.

23 Ibid. Lihat juga: Rusdi Ridwan, Ibid.

${ }_{24}$ Ibid. Lihat juga: Rusdi Ridwan, Ibid.

${ }^{25} \mathrm{Ibid.,} \mathrm{hlm.} \mathrm{8-9.} \mathrm{Lhat} \mathrm{juga:} \mathrm{Rusci} \mathrm{Ricwan,} \mathrm{lbid.}$

${ }^{25}$ Ibid. Lihat juga: Rusdi Ridwan, Ibid. 
Samudera Pasifik belum ada perundingan. Perbatasan wilayah landas kontinen di Laut Timor antara Indonesia dan Timor Leste juga belum dirundingkan. ${ }^{27}$

Dari uraian di atas, dapatlah disimpulkan bahwa Indonesia telah berhasil memiliki perjanjian perbatasan wilayah darat dan laut (untuk laut teritorial, ZEE dan landas kontinen) di beberapa tempat dengan beberapa negara tetangga. Akan tetapi belum semua batas wilayah - darat dan laut - antara Indonesia dengan negara-negara tetangganya telah dirundingkan ataupun telah mencapai kesepakatan. Masih terdapat beberapa titik perbatasan wilayah darat dan laut yang masih "terbuka". Hal ini tentu saja berpotensi untuk timbulnya konflik perbatasan wilayah apabila tidak segera dilakukan perundingan perbatasan dengan negara-negara tetangga yang bersangkutan.

Peran Hukum Intemasional Bagi Indonesia Dalam Masalah Perbatasan Wilayah Negara.

\section{Peran Keluar bagi Indonesia}

Urain masalah perbatasan wilayah yang dihadapi oleh Indonesia di atas terdiri dari dua macam. Permasalahan Indonesia atas perbatasan wilayah yang pertama adalah permasalahan perbatasan yang timbul akibat belum adanya perjanjian perbatasan wilayah antara Indonesia dengan negara tetangga. Permasalahan perbatasan wilayah yang dihadapi Indonesia yang kedua adalah permasalahan perbatasan yang timbul meskipun sudah ada perjanjian perbatasan wilayah antara Indonesia dengan negara tetangga.

Untuk permasalahan perbatasan wilayah yang pertama, maka hukum internasional disini berperan sebagai dasar diplomasi dengan negara lain. Perbatasan wilayah darat dan laut akan diselesaikan melalui metode penyelesaian sengketa internasional, baik melalui cara negosiasi, mediasi, good offices, inquiry, atau melalui arbitrase atau pengadilan internasional. Pelancaran perang tidak dimungkinkan oleh Hukum internasional mengingat perang sudah dinyatakan sebagai tindakan yang ilegal berdasarkan Huku Internasional semenjak tahun 1945 dengan didirikannya Perserikatan Bangsa-Bangsa (PBB).

Dalam menyelesaikan permasalahan perbatasan wilayah, melalui metode penyelesaian sengketa internasional yang disepakati pihak-pihak yang berperkara, akan menggunakan sumber-sumber Hukum Internasional sebagai legal authority-nya. Sumber-sumber Hukum Internasional tersebut meliputi perjanjian-perjanjian internasional, hukum kebiasaan internasional dan prinsip-prinsip dasar Hukum Internasional yang fundamental. Di samping itu, putusan-putusan badan pengadilan intemasional maupun nasional-dan tulisan/ pendapat para ahli Hukum Internasionar dapat pula menjadi sumber Hukum Internasional, dalam hal ini sebagai sumber tambahan.

Untuk permasalahan perbatasan wilayah daratan, tentulah menggunakan prinsip-prinsip perbatasan wilayah daratan yang dapat ditemukan dari sumber-sumber Hukum Internasional. Salah satu prinsip yang dapat dipakai adalah uti posidetis, yaitu prinsip yang menyatakan bahwa wilayah suatu negara bekas jajahan negara lain adalah sama dengan wilayah negara yang menjajahnya dahulu, tidak lebih dan tidak kurang. Misalnya, wilayah Indonesia adalah sama dengan wilayah yang dijajah oleh Hindia Belanda. Ini tentu saja memerlukan

${ }^{27}$ Ibid. Lihat juga: Rusdi Ridwan, Ibjd. 
dasar hukum yang dapat ditemukan di perjanjian-perjanjian internasional yang pernah dibuat oleh negara penjajah dengan negara lain

Sedangkan untuk permasalahan perbatasan wilayah laut, perjanjian-perjanjian internasional yang dipakai sebagai dasar diplomasi dengan negara lain adalah perjanjian-perjanjian internasional yang berkaitan dengan laut, yaitu UNCLOS.

Selain permasalahan perbatasan wilayah negara yang timbul akibat belum adanya kesepakatan perbatasan wilayah negara antara Indonesia dan negara tetangga, ada pula permasalahan wilayah negara yang timbul meskipun kesepakatan perbatasan sudah terbentuk sebelumnya. Misalnya, permasalahan bergesernya patok-patok perbatasan wilayah antara indonesia dan Malaysia di Kalimantan. Dalam kasus ini, secara Hukum Internasional, perbatasan wilayah antar negara tetap tidak bergeser meskipun patok-patok perbatasan ini berubah tempat. Hal ini dikarenakan perbatasan wilayah yang menjadi dasar yang resmi adalah titik-titik koordinat yang tertuang dalam perjanjian perbatasan wilayah daratan antara Indonesia dan Malaysia. Patok-patok tersebut "hanyalah" merupakan tanda batas saja. Sepanjang titik-titik koordinat di dalam perjanjian perbatasan darat antara Indonesia dan Malaysia tidak berubah, maka perbatasan wilayah daratan antara kedua negara tidaklah berubah. Demikian pula dalam kasus reklamasi pantai Singapura.

Akan tetapi, meskipun dari sisi Hukum Internasional, permasalahan bergesernya patok perbatasan di Kalimantan dan reklamasi pantai di Singapura ini tidak mempengaruhi batas wilayah yang telah disepakati bersama antara Indonesia dan negara tetangga, permasalahan batas wilayah ini tetap perla diwaspadai dan ditindaklanjuti oleh Indonesia. Indonesia tidak dapat membiarkan saja kejadiankejadian bergesernya patok dan reklamasi pantai ini. Indonesia tetap memiliki hak (bahkan kewajiban) untuk memelihara wilayah negaranya dengan berdasarkan Hukum Internasional, yang salah satunya berdasarkan perjanjian perbatasan wilayah antar negara yang telah terbentuk. Nota protes tetap harus dilayangkan untukmengingatkan negara jiran akan tindakannya yang berpotensi merugikan Indonesia. Khusus masalah reklamasi pantai yang dilakukan Singapura, negara ini sangat gencar melakukan reklamasi pantainya sehingga garis pantai asalnya berubah. Hal ini berpotensi dapat menyulitkan Indonesia dikemudian hari dalam menetapkan batas wilayah laut yang belum ditentukan antara kedua negara. Singapura dapat mengkalim batas lautnya berdasarkan garis pangkal yang baru karena garis pangkal yang lama sudah tidak dapat diidentifikasi lagi. Selain itu, berdasarkan Pasal 11 UNCLOS, instalasi pelabuhan permanen yang terluar yang merupakan bagian integral dari sistem pelabuhan, dianggap sebagai bagian dari pantai, sehingga dapat dipakai untuk penetapan batas laut teritorial. Faktanya Singapura telah mendirikan instalasi pelabuhan permanen di daratannya yang merupakan hasil reklamasi pantainya.

Disamping itu, permasalahan perbatasan wilayah yang timbul meskipun sudah terbentuk perjanjian perbatasan wilayah antar Indonesia dengan negara-negara tetangga ini dapat diselesaikan dengan jalur Hukum Internasional, jalur hukum nasional dan jalur non hukum pun (politik, ekonomi, sosial dan budaya) sangat penting untuk diterapkan. Hal ini disebabkan karena Hukum Internasional tidak dapat menyelesaikan permasalahan semacam ini secara mandiri. Permasalahan penegakan hukum 
nasional pun mempengaruhi keberhasilan penyelesaian batas wilayah antar negara yang timbul setelah perjanjian perbatasan wilayah negara tercapai antarnegara. Selain itu, manajemen perbatasan dengan pendekatan politik, ekonomi, sosial dan budaya mempunyai perannya juga disini. Jangan sampai warga negara Indonesia lebih merasa menjadi warga negara tetangga hanya karena, misalnya, mereka lebih mudah mendapatkan bahan makanan pokok, atau lebih mengenal menteri negara tetangga daripada menteri Indonesia hanya karena televisi dan radio mereka lebih mudah menangkap sinyal dari negara tetangga dibandingkan sinyal televisi dan radio negara sendiri.

\section{Peran Ke dalam Indonesia}

Dalam tataran praktik, ada kecenderungan setiap negara memastikan bahwa Hukum Nasionalnya senafas dengan Hukum Intemasional. Demikian pula dengan Indonesia. Dengan diratifikasinya UNCLOS, maka Indonesia kemudian mengubah Deklarasi Pemerintah Th. 1957 jo. UndangUndang No. 4 Prp. Th. 1960 menjadi Undang-Undang No. 6 Th. 1996 tentang Perairan Indonesia. Hal ini disebabkan karena Deklarasi Pemerintah Th. 1957 jo. UU No. 4Th. 1960 sudah tidak mengakomodasi nafas UNCLOS ditataran Hukum Nasional Indonesia. ${ }^{28}$

Di samping itu, Indonesia pun telah menetapkan alur-alur laut kepulauan, yang merupakan salah satu hak yang dimiliki oleh Negara Kepulauan seperti yang diatur dalam UNCLOS. Hal ini kemudian dituangkan ke dalam Peraturan Pemerintah No. 37 Th. 2002 tentang Hak dan Kewajiban Kapal dan Pesawat Udara Asing dalam Melaksanakan Hak Lintas Alur Laut Kepulauan Melalui Alur Laut Kepulauan yang Ditetapkan..29
Akan tetapi, dalam kaitannya dengan PP No. 37 Th. 2002 di atas, peraturan ini seharusnya sudah diubah setelah Mahkamah Internasional PBB memutuskan bahwa Pulau Sipadan dan Ligitan menjadi bagian wilayah Malaysia. PP ini sampai saat ini masih berlaku, padahal PP ini memasukkan Pulau Sipadan dan Ligitan ke dalam wilayah Indonesia.

Di samping itu, dalam kaitannya dengan kewajiban negara Indonesia untuk mematuhi Perjanjian Intemasional yang telah diratifikasinya, ${ }^{30}$ dalam hal ini UNCLOS, maka adalah suatu kewajiban bagi negara Indonesia untuk mencantumkan peta dan daftar koordinat geografis dari garis pangkal, batas luar ZEE dan batas luar dari landas kontinen Indonesia. Selain itu, peta dan daftar koordinat ini harus didaftarkan dan diumumkan di Sekretariat Jenderal PBB. Selama ini, Indonesia belum memiliki peta berskala dan daftar koordinat geografis untuk garis pangkal, batas luar ZEE dan batas luar landas kontinen. Indonesia baru memiliki peta ilustratif perairan Indonesia yang merupakan lampiran dari UU No. $6 \mathrm{Th} .1996$. Hal ini perlu diwaspadai dan ditindaklanjuti oleh Indonesia, karena dengan rawannya perbatasan wilayah laut Indonesia di beberapa titik, maka dengan dimilikinya dan didaftarkannya peta berskala dan daftar

${ }^{28}$ Adi Sumardiman, "Beberapa Dasar tentang Perbatasan Negara", Jumal Hukum Intemasional Vol.I No.3, April 2004, him.504-507

${ }^{29} \mathrm{Ibid}, \mathrm{hlm} .462-463$

30 Hal ini dkenal sebagai pacta sunt servanda, yaitu sebuah perjanjian akan melahirkan hak dan kewajiban internasional bagi pihak-pihaknya saja. Dengan kata Jain, apabila telah meratifikasi perjanjian internaisonal itu maka negara tersebut mempunyai kewajiban untuk mentaati dan melaksanakan segala aturan yang tercantum dalam perjanjian itu. 
koordinat geografis ini sangatlah membantu Indonesia dalam menyelesaikan permasalahan perbatasan wilayah laut dengan negara-negara tetangga yang belum terselesaikan dengan tuntas.

\section{Penutup}

Dari uraian di atas, maka dapat disimpulkan bahwa wilayah adalah salah satu unsur terpenting dalam suatu negara. Tanpa ada wilayah, maka tidak akan ada suatu negara. Perubahan dan ketidakjelasan batas wilayah negara tidaklah mempengaruhi status hukum dari suatu negara. Akan tetapi, ketidakjelasan batas wilayah ini akan membuka pintu konflik antara negara-negara yang bertetangga.

Dalam permasalahan perbatasan wilayah negara ini, Hukum Internasional mempunyai peran, baik keluar maupun ke dalam, bagi Indonesia. Peran keluar adalah untuk dasar diplomasi Indonesia dengan negara lain dalam menyelesaikan masalah perbatasan wilayah negara. Sedangkan peran Hukum Intemasional ke dalam adalah untuk mengharmonisasikan antara Hukum Internasional dengan Hukum Nasional. Pengharmonisasian ini dapat melaiui cara inkorporasi (Hukum Internasional otomatis masuk ke dalam tataran Hukum Nasional tanpa ada tindakan adopsi kedalam Hukum Nasional) ataupun dengan cara transformasi (Hukum Internasional baru dapat masuk ke dalam Hukum Nasional apabila telah melalui proses transformasi ke dalam Hukum Nasional, seperti misalnya dengan cara pengundangan di tataran Hukum Nasional). Sehingga Hukum Nasional Indonesia yang berkaitan dengan perbatasan wilayah negara - baik darat maupun laut - akan senafas dengan kewajiban Hukum Internasional.
Dalam tataran praktis, Indonesia telah menggunakan Hukum Intemasional sebagai bantuan melancarkan diplomasi keluar dalam menyelesaikan permasalahan perbatasan wilayah negara. Akan tetapi diplomasi Indonesia ditataran internasional tidaklah berjalan dengan sendirinya. Diplomasi Indonesia yang berlandaskan Hukum Internasional ini perlu dukungan penuh dari kekuatan dan penegakan Hukum Nasional yang bersih dan berwibawa. Selain itu, aspek-aspek non yuridis, seperti aspek politik, ekonomi, sosial dan budaya pun ikut andil dalam keberhasilan manajemen perbatasan wilayah negara Indonesia.

Oleh karena itu, Indonesia perlu secepatnya memperbaharuj Hukum Nasional, khususnya yang berkaitan langsung maupun tidak langsung dengan batas wilayah negara, yang sudah tidak sepaham dan tidak mengakomodasikan Hukum Internasional lagi. Dengan pembaharuan Hukum Nasional yang berkaitan dengan batas wilayah negara ini, pelaksanaan Hukum Internasional yang konsisten, serta dan penegakan hukum yang bersih dan berwibawa, maka akan memberi kejelasan atas perbatasan wilayah negara Indonesia dengan negara-negara tetangga di dunia internasional. Hal ini akan lebih memperlancar usaha diplomasi Indonesia dalam penyelesaian persengketaan perbatasan wilayah negara dengan negaranegara tetangganya. $\Theta$

\section{Daftar Pustaka}

Adi Sumardiman, "Beberapa Dasar tentang Perbatasan Negara", Jumal Hukum Intemasional Vol. I No.3, April 2004.

John O'Brien, 2001, International Law Cavendish, London: Blackstone. 
Topik: Manajemen Negara dan Nasionalisme

Martin Dixon, 2000, Textbook on Intemational International Law, 4th Ed. London:

R.R. Churchil dan A.V. Lowe, 1991, The Law of the Sea, 2nd Ed, Manchester, U.K.

Rusdi Ridwan,2005, "Batas Maritim antara Republik Indonesia dengan Negara Tetangga", Makalah yang disampai- kan dalam Seminar Batas Wilayah Negara, Teknik Geodesi UGM, 3 Mei 2005

Sobar Sutisna,2005, "Batas-batas internasional NKRI", Makalah yang disampaikan dalam Seminar Batas Wilayah Negara, Teknik Geodesi UGM, 3 Mei 2005. 